\title{
Assessment of the conservation priority status of South African estuaries for use in management and water allocation
}

\author{
JK Turpie $^{1 *}$, JB Adams², A Joubert ${ }^{3}$, TD Harrison ${ }^{4}$, BM Colloty $^{2}$, RC Maree ${ }^{5}$, AK Whitfield $^{6}$, TH \\ Wooldridge $^{7}$, SJ Lamberth ${ }^{5}$, S Taljaard ${ }^{8}$ and L Van Niekerk ${ }^{8}$ \\ ${ }^{1}$ Percy FitzPatrick Institute of African Ornithology, University of Cape Town, Rondebosch 7701, South Africa \\ ${ }^{2}$ Botany Department, University of Port Elizabeth, P.O Box 1600, Port Elizabeth, 6000, South Africa \\ ${ }^{3}$ Department of Statistical Sciences, University of Cape Town, Rondebosch 7701, South Africa \\ ${ }^{4}$ CSIR, Division of Water, Environment and Forestry Technology (Environmentek), PO Box 17001, Congella 4013, \\ Durban, KwaZulu-Natal, South Africa \\ 5.Marine and Coastal Management, Private Bag X2, Roggebaai 8012, South Africa \\ ${ }^{6}$ JLB Smith Institute of Ichthyology, Private Bag 1015, Grahamstown 6140, South Africa \\ 'Zoology Department, University of Port Elizabeth, P.O Box 1600, Port Elizabeth, 6000, South Africa \\ ${ }^{8} \mathrm{CSIR}$ Environmentek, PO Box 320, Stellenbosch, South Africa
}

\begin{abstract}
The future health and productivity of South Africa's approximately 250 estuaries is dependent on two main factors: management and freshwater inputs. Both management and water allocation decisions involve trade-offs between conservation and various types of utilisation. In order to facilitate decision-making in both of these spheres, it is necessary to understand the relative conservation importance of different estuaries. This study devises a method for prioritising South African estuaries on the basis of conservation importance, and presents the results of a ranking based on the collation of existing data for all South African estuaries. Estuaries are scored in terms of their size, type and biogeographical zone, habitats and biota (plants, invertebrates, fish and birds). Thirtythree estuaries are currently under formal protection, but they are not representative of all estuarine biodiversity. We performed a complementarity analysis, incorporating data on abundance where available, to determine the minimum set of estuaries that includes all known species of plants, invertebrates, fishes and birds. In total, 32 estuaries were identified as 'required protected areas', including 10 which are already protected. An estuary's importance status (including 'required protected area' status) will influence the choice of management class and hence freshwater allocation under the country's new Water Act, and can be used to assist the development of a new management strategy for estuaries, which is currently underway.
\end{abstract}

\section{Introduction}

There are approximately 250 functional estuaries in South Africa (Whitfield, 2000), together making up about 70000 ha of one of the country's most productive habitats. Estuaries are well-known for their biodiversity, productive fish and invertebrate fisheries and for the important functions that they perform, such as providing nursery areas for marine fish, conduits for species which move between ocean and rivers (e.g. some eels and invertebrates) and feeding and staging sites for significant populations of migratory birds (Skelton, 1993; Turpie 1995). They also support a number of endemic species, many of which depend on estuaries for their survival. However, estuaries constitute one of the most threatened habitats in the country. In the past few decades there has been a plethora of marina and resort developments, reclamation and increasing human disturbance and exploitation. In many cases, freshwater inflows, vital to the maintenance of salinity profiles, sediment scouring and nutrient supply, have been siphoned off or polluted. As a result of all of these pressures, many South African estuaries have become functionally degraded, and this has frequently been accompanied by a loss of species (e.g. Goliath Heron from the Swartkops, Estuarine Pipefish from the Kariega - Whitfield, 1998) or a reduction in populations (Love, 2000; Wooldridge, 1999).

\footnotetext{
* To whom all correspondence should be addressed

푱 021650 3302; fax: 021650 3295; e-mail: jturpie@botzoo.uct.ac.za Received 20 November 2000; accepted in revised form 20 March 2002
}

The future health of South Africa's estuaries is dependent on two main factors: their direct management and the quantity and quality of freshwater inputs. Very little consideration has been given to either in the past, but both of these aspects are currently under review in South Africa. Their management has now been entrusted to Marine \& Coastal Management, Department of Environment Affairs \& Tourism by the Marine Living Resources Act (Act 18 of 1998), and their water allocation is now being considered under the new National Water Act (Act 36 of 1998). Through the resource-directed measures (RDM) process, the latter will ensure a freshwater supply or 'reserve' for estuaries to maintain their ecological functioning, but the level of the reserve may vary, depending on socio-economic goals, to maintain estuaries in anything from a near-pristine state to a satisfactorily-functioning, but altered state (Adams et al., 1999).

Relative conservation importance is an important consideration in the decision-making processes regarding the management of or freshwater allocation to estuaries. Because of the demands for consumptive and non-consumptive use of estuaries, and for water from their catchments, it is not practical to ensure the high-quality functioning of all South African estuaries. Thus it is essential to formulate a sound way of prioritising estuaries in terms of their conservation importance, and to use this in determining the ways in which estuaries are managed and to what extent their water requirements are secured. The quantity and quality of water allocated to the estuarine reserve will be determined by the management class assigned to an estuary. Management class, in turn, will be assigned on the basis of an estuary's health and 
importance as well as other socio-economic considerations, the methodology for which is under development.

The aims of this study were to:

- develop a method to determine the conservation importance of estuaries;

- prioritise South African estuaries on the basis of existing information; and

- $\quad$ propose an efficient network of estuarine protected areas.

On the basis of the above, recommendations are made regarding the use of these findings in:

- determining an estuary's management class, and hence water reserve; and

- developing a workable system of estuary management.

\section{Methods}

\section{Prioritisation of estuaries}

The study began with a review of existing methods to prioritise estuaries on the basis of different criteria. Following this, we selected criteria and devised weightings and an overall index during two workshops attended by a selection of the country's top estuarine specialists. Data on the relevant biophysical attributes of South African estuaries were obtained from published and unpublished data sets. Estuaries were prioritised on the basis of the developed index, the methodology for which is described in detail below.

\section{Identification of a minimum required set of estuarine protected areas (EPAs)}

Using existing data, present EPAs (estuaries which are fully or partly protected as national parks, nature reserves etc.) were analysed in terms of their representativeness of the country's estuarine biodiversity. Following this, complementarity analysis was carried out to determine the minimum set of estuaries that would represent all estuarine species (in estuaries supporting viable populations), as far as could be determined.

A complementarity analysis is an iterative selection technique, which identifies how the greatest diversity of species can be conserved at the minimum number of sites (Pressey et al., 1993). Such analyses can vary in terms of approach and type of algorithms used. In this study a rarity algorithm was used, which gives priority to sites containing the highest number of rare species. Each site is assigned a rarity value:

$$
\text { Rarity }=\sum_{i=1}^{n} \frac{k}{a_{i}}
$$

where:

$\mathrm{k}$ is the total number of estuaries, and

$\mathrm{a}_{\mathrm{i}}$ is the number of estuaries containing the $i$ th species.

The analysis begins by identifying the site with the highest rarity value. This site is then considered reserved, and all species occurring at this site are removed from the analysis. Subsequent steps repeat this procedure until all species are included in the reserved sites. Thus, each consecutively selected site conserves species that have not been conserved in any of the previous sites.

Using a simple presence-absence database, complementarity analysis selects the minimum set of sites in which each species is included at least once. This algorithm can be altered to represent each species in more than one estuary, if required. There is, however, a danger in this approach, in that a species may be designated as 'conserved' at a site where it is insufficiently abundant to ensure its long-term survival. In order to circumvent this problem in the simplest mathematical way, abundance can be taken into account, whilst still using a presence-absence algorithm. Where data on abundance were available, species were only counted as present at the sites where they are most abundant (e.g. the top five sites), or where at least $10 \%$ of the total coastal population occurs.

For the complementarity analyses, the plant, invertebrate, fish and bird datasets were refined to include only estuarine species (e.g. excluding intrusive marine and freshwater species that are only occasionally recorded in estuaries or at estuary mouths). For fish and birds, abundance data were used to refine the presenceabsence datasets to the top five estuaries for each species.

\section{Prioritising estuaries: A review of issues and methods}

From a conservation standpoint the notion of importance of an area is usually based on two main concepts:

- rarity, pertaining to rare physical types, rare habitats or rare species, where rarity implies scarcity, and means limited abundance or geographical range; and

- quantity (= abundance), pertaining to size, habitat area and diversity, species diversity, population size, and productivity.

A third component which should be considered is ecosystem function (e.g. nursery areas for marine fish), although this is usually very difficult to quantify in practice.

It may be argued that the importance of an estuary is influenced by its health status. Thus the question arises as to whether health status should be taken into consideration. Indeed, an estuary may even be more important in its altered state than in its pristine state. An example of this is the Mhlatuze system, where a change in hydrology and morphology has allowed colonisation of large areas by mangroves, with the result that this estuary now contains a major proportion of the country's mangroves. However, a more holistic look at the estuary would establish that the hydrological and morphological changes have also led to an equally or more important loss in ecosystem function, in that important lacustrine components of the previous Richards Bay have been lost. However, since the practical implications of determining the extent of deviation of an estuary from its pristine state are immense, and because altered states usually cause a decline in conservation status which should be reflected in a comprehensive index, we confined this study to determining the priority status of estuaries in their current state.

Although several indices have been developed, few countrywide assessments have been completed of the priority status of different estuaries in South Africa. Turpie (1995) used existing count data to explore methods and criteria for determining the importance of different estuaries for birds. Detailed summer counts of nonpasserine waterbirds (species wholly or partially dependent on aquatic habitats) exist for most of South Africa's estuaries, with the exception of the Transkei region. Many of these data came from a published series of single summer counts of coastal wetlands that was carried out systematically around the coast during the two summer periods between 1979 and 1981 (Ryan and Cooper, 1985, Ryan et al., 1988, Underhill and Cooper, 1984, Ryan et al., 1986). On the basis of these counts, there are estimates of the total coastal population of each species. Estuaries were ranked according to 
TABLE 1

Criteria used to evaluate importance of estuaries for fish in the FIR (Maree et al., 2000)

\begin{tabular}{|l|l|l|l|l|l|l|}
\hline \multicolumn{2}{|c|}{ Measures of species importance } & \multicolumn{4}{|c|}{ Measures of estuarine importance } \\
\hline $\begin{array}{l}\text { Number of } \\
\text { exploitable } \\
\text { species }\end{array}$ & $\begin{array}{l}\text { Number of } \\
\text { estuarine- } \\
\text { dependent } \\
\text { species }\end{array}$ & $\begin{array}{l}\text { Number of } \\
\text { endemic } \\
\text { species }\end{array}$ & Type & Size & Condition & Isolation \\
\cline { 4 - 7 } & & $\begin{array}{l}\text { Estuarine bay }> \\
\text { Permanently open }> \\
\text { Estuarine lake }> \\
\text { Temporarily closed }> \\
\text { River mouth }\end{array}$ & $\begin{array}{l}\text { large }> \\
\text { small }\end{array}$ & $\begin{array}{l}\text { Excellent }> \\
\text { Good }> \\
\text { Fair }> \\
\text { Poor }\end{array}$ & $\begin{array}{l}\text { Isolated }> \\
>\end{array}$ \\
Grouped \\
\end{tabular}

species richness, species diversity (Shannon Index), rarity and conservation status. These indices tested the effect of using limited (presence-absence) as well as abundance data. With the exception of the Shannon index, which was not considered to be a useful tool for evaluating conservation importance, the resulting rankings were significantly correlated (Turpie 1995). A key point made in the study was that the final evaluation of sites should ideally involve a subjective assessment of the results of single-criterion rankings, rather than using a multicriteria index, but this may not be practical when evaluating a large number of sites on the basis of several attributes or biota.

A fish importance rating (FIR) for South African estuaries was recently devised by Maree et al., (2000). This index was constructed from seven weighted measures of species and estuarine importance (Table 1), and was designed to work on a presence-absence data set, where species were only considered to be present if they constituted more than $1 \%$ of any total catch by number. The FIR assumes a potential distribution for species by assuming that each estuarine species occurs in all estuaries within its distribution range, and hence produces a ranking for all South African estuaries. Estuarine measures are included within the FIR (Table 1) because these variables are assumed to influence abundance, and can be used as a surrogate for quantitative data. Thus, the measures of estuarine condition are scored on categories of decreasing value (Table 1) according to how they might positively or negatively affect the importance of the fish community. The estuarine importance component of the FIR should therefore be seen as an essential part of the FIR, and should not be regarded as an independent estuarine importance rating that may be removed from the species importance component.

Obtaining quantitative data for fish is particularly difficult, as different sampling methods tend to be biased towards different groups or life-history stages. However, Harrison et al. (2000) have recently carried out limited, but uniform, sampling in most estuaries, providing the opportunity for a quantitative analysis in this study.

The botanical importance rating (BIR) index, developed by Coetzee et al. (1997), assigned values to estuaries on the basis of percentage area cover of different plant habitats, their condition (degree of impact), functional importance and plant community richness. This index was constructed as follows:

$$
\begin{aligned}
\mathrm{BIR}= & 1\left(\mathrm{~A}_{\text {supra }} \times \mathrm{MF}\right)+1.75\left(\mathrm{~A}_{\text {inter }} \times \mathrm{MF}\right)+2\left(\mathrm{~A}_{\text {subm }} \times \mathrm{MF}\right) \\
& +1.5\left(\mathrm{~A}_{\text {reed }} \times \mathrm{MF}\right)
\end{aligned}
$$

where:

$\mathrm{A}_{\text {supra }}, \mathrm{A}_{\text {inter }}, \mathrm{A}_{\text {subm }}$ and $\mathrm{A}_{\text {reed }}$ are the area cover of supratidal saltmarsh (e.g. Sarcocornia pillansii), intertidal saltmarsh (e.g.
Triglochin spp.), submerged macrophytes (e.g.Zostera, Ruppia) and reed and sedge communities;

MF is a multiplication factor representing community condition; and

the weightings are community importance values based on association, or functional importance, within the estuary; i.e. water dependence, primary productivity and the richness of the community they support.

The area cover was originally a score based on percentage cover of the estuary. Thus a 5 ha estuary and a 500 ha estuary, each having the same \% cover distribution of macrophytes received the same score. This meant that the index measured health (e.g. Colloty et al., 1998), inasmuch as high scores represented a healthy and diverse plant community, irrespective of size. The index was first applied to 33 estuaries in the Cape, and the results were found to accord with the perceived botanical condition of those estuaries. The score has since been changed to use actual area, and no longer includes a measure of condition, making it more of a measure of importance. It now also includes other aspects usually associated with importance, namely species richness, community type richness and community type rarity (Colloty et al., 2000). A large proportion of South African estuaries has now been surveyed for plants, and a database exists which includes the components and scores of the index, in addition to species lists.

In the only attempt at constructing an importance rating of South African estuaries based on multiple attributes, the Consortium for Estuarine Research and Management (CERM, 1996) devised an index which incorporated a rarity, biological and physical value score (Table 2). The index included many critical elements, but its main drawback for application in the context of this study is that it combines measures of health and importance. The rarity criteria include three measures of importance and one of health. Most of the biological criteria are measures of importance, except the fish index, which includes a health score based on difference from the reference community. All the physical criteria are measures of health that assess the difference between present and reference state (the reference state refers to conditions that are assumed to have existed prior to anthropogenic impacts and is largely based on freshwater supply patterns). Nevertheless, the method was not implemented due to a lack of biotic data for estuaries, particularly those in the former Transkei and Ciskei (CERM, 1996). Since then both fish and botanical surveys have taken place in these areas and the opportunity now arises to develop further an overall importance rating system for South African estuaries. 


\begin{tabular}{|c|c|c|c|c|c|}
\hline \multicolumn{6}{|c|}{$\begin{array}{l}\text { TABLE } 2 \\
\begin{array}{c}\text { Criteria and score construction of CERM's (1996) proposed importance } \\
\text { rating system }\end{array}\end{array}$} \\
\hline \multicolumn{2}{|l|}{ Rarity } & \multicolumn{2}{|c|}{ Biological } & \multicolumn{2}{|l|}{ Physical } \\
\hline Criterion & Score & Criterion & Score & Criterion & Score \\
\hline $\begin{array}{l}\text { Estuarine type } \\
\text { Geomorphology type } \\
\text { Size } \\
\text { Condition }\end{array}$ & $\begin{array}{l}0-25 \\
0-25 \\
0-25 \\
0-25\end{array}$ & $\begin{array}{l}\text { Habitat } \\
\text { Plants } \\
\text { Inverts } \\
\text { Fish } \\
\text { Birds }\end{array}$ & $\begin{array}{l}0-20 \\
0-20 \\
0-20 \\
0-20 \\
0-20\end{array}$ & $\begin{array}{l}\text { Siltation } \\
\text { Tidal exchange } \\
\text { Water quality } \\
\text { Hydrodynamics }\end{array}$ & $\begin{array}{l}0-26 \\
0-33 \\
0-19 \\
0-22\end{array}$ \\
\hline TOTAL & $0-100$ & TOTAL & $0-100$ & TOTAL & $0-100$ \\
\hline
\end{tabular}

TABLE 3

Possible variables for inclusion in an estuarine importance index. Variable categories are rarity $(R)$, abundance $(A)$ and ecological function (F)

\begin{tabular}{|l|c|c|}
\hline Variable & $\begin{array}{c}\text { Type } \\
\text { Selected in } \\
\text { this study }\end{array}$ \\
\hline 1. Estuary size & A & $\checkmark$ \\
2. Rarity of the estuarine type in relation to geographic area & R & $\checkmark$ \\
3. Habitat diversity & A, F & $\checkmark$ \\
4. Biodiversity importance in terms of plants, invertebrates, fish and birds. & R, A, F & $\checkmark$ \\
5. Proximity of other estuaries & R, F & $\times$ \\
6. Ecological services to neighbouring environments & F & $\checkmark$ \\
7. The sensitivity and resilience of the system to environmental change. & - & $\mathbf{x}$ \\
8. Naturalness & - & $\mathbf{x}$ \\
9. Conservation status, e.g. protected area, Ramsar or natural heritage site. & F & $\mathbf{x}$ \\
10. Marine, estuarine and freshwater linkages & & \\
\hline
\end{tabular}

\section{Methodology for determining estuarine conservation importance}

\section{Identification of attributes for inclusion in the index}

Ecological importance is an expression of the importance of a particular estuary to the maintenance of ecological diversity and functioning on local and wider scales. Some of the variables that can be considered as the basis for the estimation of ecological importance of an estuary are listed in Table 3 . These variables can each be categorised as measures of rarity, abundance or ecological function.

These variables were discussed in a workshop setting, regarding their suitability for inclusion in an estuarine importance index. Size was initially rejected because it is a driving variable for diversity and abundance of biota, and is thus likely to be highly correlated with these. However, it is included because of the general paucity of information on the abundance of certain biota. It was agreed that sensitivity of an estuary does not confer importance, although it does become an important issue in setting freshwater requirements and in management. Similarly, naturalness was not considered as an appropriate indicator of importance, as it has more of an estuarine health connotation. Proximity of other estuaries is partially covered by the rarity variable. Conservation status does not confer importance per se; it is, however, an important consideration in determining the management class of estuaries, as we will argue later in this paper. Treatment of the selected variables is discussed below.

\section{Attribute scoring systems and data availability}

\section{Size}

Estuary size is defined as the total area (ha) within the geographical boundaries described in the RDM methodology (Adams et al., 1999). Area data for $89 \%$ of estuaries was compiled primarily from Colloty (2000), using supplementary information from Cowan and Van Riet (1998) and CERM (1996). There are several discrepancies between these sources, due to different definitions of estuarine boundaries, with the primary source tending towards higher estimates of area because of its inclusion of the floodplain area.

\section{Link with freshwater and marine environments}

Estuaries provide several ecological services to their surrounding environments, particularly the marine environment. These include:

- Export of detritus, nutrients and sediment to the coastal zone

- Nursery function for various marine-living fish and crustaceans

- Nursery function for freshwater organisms (e.g. river prawns such as Macrobrachium spp.)

- Movement corridor for migratory invertebrates (e.g. river crab Varuna littoralis) and fishes (e.g. anguillid eels)

- Roosting areas for marine or coastal birds. 


\begin{tabular}{|c|c|c|c|}
\hline \multicolumn{4}{|c|}{$\begin{array}{c}\text { TABLE } 4 \\
\text { Whitfield's (1992) physical classification of estuaries }\end{array}$} \\
\hline Type & Tidal prism & Mixing process & Average salinity * \\
\hline $\begin{array}{l}\text { Estuarine bay } \\
\text { Permanently open } \\
\text { River mouth } \\
\text { Estuarine lake } \\
\text { Temporarily closed }\end{array}$ & $\begin{array}{c}\text { Large }\left(>10 \times 10^{6} \mathrm{~m}^{3}\right) \\
\text { Moderate }\left(1-10 \times 10^{6} \mathrm{~m}^{3}\right) \\
\text { Small }\left(<1 \times 10^{6} \mathrm{~m}^{3}\right) \\
\text { Negligible }\left(<0.1 \times 10^{6} \mathrm{~m}^{3}\right) \\
\text { Absent }\end{array}$ & $\begin{array}{l}\text { Tidal } \\
\text { Tidal/riverine } \\
\text { Riverine } \\
\text { Wind } \\
\text { Wind }\end{array}$ & $\begin{array}{c}20-35 \\
10->35 \\
\quad<10 \\
1->35 \\
1->35\end{array}$ \\
\hline
\end{tabular}

\begin{tabular}{|c|c|c|c|c|c|c|}
\hline \multicolumn{7}{|c|}{$\begin{array}{c}\text { TABLE } 5 \\
\text { Number of estuaries of each physical type in each biogeographical } \\
\text { zone, and their ZTR scores }\end{array}$} \\
\hline & \multicolumn{2}{|c|}{ Cool temperate } & \multicolumn{2}{|c|}{ Warm temperate } & \multicolumn{2}{|c|}{ Subtropical } \\
\hline & Number & Score & Number & Score & Number & Score \\
\hline Estuarine bay & 0 & - & 1 & 100 & 3 & 33 \\
\hline Permanently open & 2 & 50 & 29 & 3 & 16 & 6 \\
\hline River mouth & 2 & 50 & 6 & 17 & 4 & 25 \\
\hline Estuarine lake & 0 & - & 4 & 25 & 4 & 25 \\
\hline Temporarily closed & 5 & 20 & 85 & 1 & 94 & 1 \\
\hline
\end{tabular}

We proposed the calculation of a functional index score which ranges from zero (of no importance) to 100 (extremely important) for each. However, there is no collated information at this stage on functional importance of estuaries, and it was not possible to include this attribute in this study.

\section{Rarity of estuary type with reference to geographic position}

South African estuaries have been classified into five types (Table 4, Whitfield, 1992). There are only four estuarine bays and eight estuarine lakes in the country, therefore these systems are important in terms of rarity. If biogeographical zonation is also taken into consideration, then the classification of an estuary in conjunction with the biogeographical zone determines how "rare" or "unique" the estuary is for the zone under consideration. For example there are only two permanently open estuaries (Olifants and Berg) in the cool temperate west coast zone and therefore these systems are of national importance (Table 5). The Palmiet Estuary in the southwestern Cape is the only system along that stretch of coastline that remains open for any length of time, and is thus very important in this region for fish and invertebrate recruitment. Thus, a zonal type rarity score was devised, as follows:

$$
\mathrm{ZTR}=100 \times 1 / \mathrm{N}_{\mathrm{tz}},
$$

where:

$N_{t z}$ is the number of estuaries of type $t$ within the same biogeographical zone $z$.

This yields scores in the range of 1 to 100 (Table 5).

\section{Habitat diversity}

An estuary can be considered more important if it has a high diversity of habitat types, or on the basis of habitat representativeness, in terms of the size and rarity of those habitat types that it contains. Estuarine habitats include physical (unvegetated) habitats such as channel area, sandflats, mudflats, and rock, and plant communities, such as salt marsh, mangroves, submerged macrophytes, reeds and sedges. Habitat information is available for $92 \%$ of the country's estuaries (Colloty, 2000).

A habitat rarity score was designed to take into consideration the number of habitats in an estuary, and the extent to which rare habitats occur within the estuary, as follows:

$$
H R=1000 x \sum_{i=1}^{n} \frac{a_{i}}{A_{i}}
$$

where:

$\mathrm{a}_{\mathrm{i}}$ is area of the $i$ th habitat in the estuary and

$A_{i}$ is the total area of that habitat in the country (Table 6).

The multiplication factor is necessary because without it the score yields very small values, such that the sum of all scores for all estuaries is equal to the number of habitats considered. The plant community type areas have been measured for a large proportion of South African estuaries (Table 6).

It should be borne in mind that several of these habitat categories undergo dynamic changes in area over the medium to long term (e.g. Cooper, 1991; Colloty et al., 2000). Natural changes in habitat areas are a major consideration in assessing estuarine importance with respect to habitats. Any snapshot measurement only records habitats at one particular part of an estuary's cycle. Thus snapshot measures of potentially highly unstable elements, such as Zostera capensis cover, do not reflect the range or average level of availability 


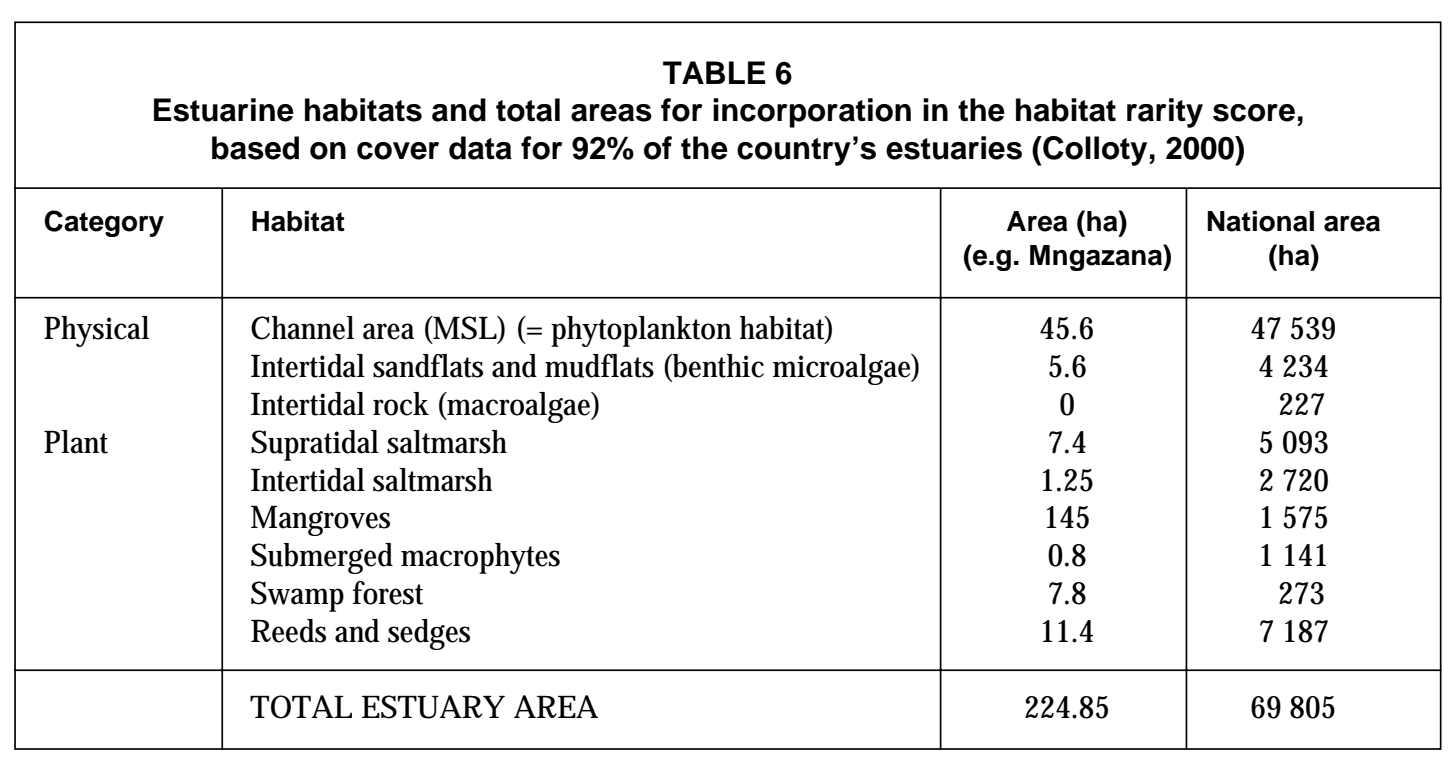

of that habitat. Ideally, this should be dealt with by using the estimated mean level of abundance over the full range of existing conditions.

\section{Biodiversity importance}

The four main biotic groups - plants, invertebrates, fish and birds, were selected for inclusion in a biodiversity importance score. The scoring for each group should ideally incorporate the following elements:

- species richness;

- $\quad$ species rarity or endemism; and

- abundance (numbers, area or biomass).

Here it is argued that a species rarity score would suffice as a measure of biodiversity importance for each group, as it incorporates all of these aspects.

South African estuaries fall within three broad biogeographical zones. The cool temperate zone extends from north of Walvis Bay in Namibia to Cape Point; the warm temperate zone from Cape Point to about Mbashe and the subtropical zone extends north from Mbashe (Whitfield, 1998). Faunal composition therefore changes around the coast, with the highest number of species associated with warm temperate and subtropical systems, and highest productivity associated with the west coast (Whitfield and Marais, 1999; De Villiers et al., 1999; Turpie et al., 2000). A species richness-dominated index would thus result in a general increase in importance from west to east. Taking abundance into account will temper this trend to some extent. Nevertheless, biogeographic zonation is an important aspect to take into account when selecting protected areas, as discussed in the following sections.

Thus, where possible, the biodiversity importance index should use abundance data, but it is recognised that in some cases (e.g. invertebrates), estimates of overall abundance, or presence-absence data will have to suffice. Species rarity is usually described in terms of red data status, rarity in terms of occurrence at all sites, or endemism (important by virtue of the fact that they have restricted ranges and occur mainly or entirely in South Africa). The species rarity index, which is a simple addition of a score for each species in the system, tending to give weight to the species that fall in any of these categories, is constructed as follows:

$$
S R I=100 x \sum_{i=1}^{n} r_{i}
$$

where:

$r_{i}$ is the rarity score of the ith species.

The multiplier is smaller than for the habitat index because the larger number of species makes the index values larger. The way in which the rarity score for each species can be calculated differs depending on the level of data available, as follows. With abundance data:

$$
r_{i}=q_{i} / Q_{i},
$$

where:

$\mathrm{q}_{\mathrm{i}}=$ number (or area) in estuary; and

$\mathrm{Q}_{\mathrm{i}}=$ total number (or area) in all South African estuaries.

With species presence-absence data only:

$$
r_{i}=1 / N_{i}
$$

where:

$\mathrm{N}_{\mathrm{i}}=$ the number of estuaries in which the species occurs in South Africa.

If possible, presence-absence data should be refined to only include species as present where they are known or thought to be in viable population numbers. Scores calculated using abundance are far more sensitive than scores based on presence-absence, and will tend to produce lower species weights. An estuary will score more highly if there are more species, and more highly if there are many rare species.

There are no abundance data for plant species per se, but plant species lists have been compiled for $92 \%$ of South African estuaries (Colloty, 2000). A dataset of 264 estuarine invertebrate species was compiled based on distribution data (Awad et al., 2000; Emanuel et al., 1992; Day, 1967a;b; Branch et al., 1994) and estuary type (Whitfield, 2000). All estuaries within the range of a species were assumed to contain these species, except those marine species which tend to occur at the mouths of permanently open estuaries were not considered present in temporarily closed estuaries. This dataset thus overestimates the presence of species, as it assumes the maximum possible diversity within each estuary, 
TABLE 7

Calculation of the biodiversity importance score

\begin{tabular}{|l|c|c|}
\hline Parameter & e.g. Nahoon & Weight \\
\hline Plant importance score & 90 & 25 \\
Invertebrate importance score & 60 & 25 \\
Fish importance score & 80 & 25 \\
Bird importance score & 70 & 25 \\
\hline Mean score & 75 & 50 \\
Max score & 90 & 50 \\
\hline Biodiversity importance score & 82.5 & \\
\hline
\end{tabular}

without accounting for the fact that the actual species present will depend on estuary size, type and habitat availability. In future, the dataset will be refined as more estuaries are surveyed.

Two datasets are available for estuarine fish. The first was compiled by Maree et al. (2000), and comprises both hypothetical presence-absence data based on known distributions and a presenceabsence database based on actual records of species in estuaries. The second, compiled by Harrison et al. (2000), contains empirical abundance and biomass data obtained in a single sampling effort of most of the country's estuaries. The latter are thus generally comparable from estuary to estuary. For analysis, abundance data were used to create a presence-absence dataset with species being considered present at the top five sites or where their numbers exceeded $10 \%$ of the total estuary sample.

Similarly, empirical species records and abundance data for birds are available for a large number (178) of South African estuaries, and having been ascertained in a single sampling effort, are comparable from estuary to estuary. Bird abundance data were used to refine the presence-absence dataset to species being considered present at the top five sites or where their numbers exceeded $10 \%$ of the total coastal population (Turpie, 1995).

Once aligned to a common scoring base (see below), the results of the four biotic indices can either be weighted and summed in a combined index or subjectively assessed to create an overall ranking. Subjective ranking could be justified, in that it would avoid the dampening effect that may result if an estuary were important according to one attribute, but had low corresponding values for other attributes. A resulting low overall rank, may not alert the expert to the fact that the estuary is important for one particular reason. However, in this study there are too many estuaries to make a subjective ranking viable. One could create a composite index, eliminate those sites with very low scores and then subjectively re-rank the higher-ranking sites. Alternatively, the method of aggregation could take into account the maximum attribute value as well as the weighted average values. Therefore, an estuary will score relatively highly if it were important for one taxonomic group as well as if it were important for all groups. The overall score is thus obtained by using the maximum score obtained in the four groups, as well as the weighted average score, as follows:

Biodiversity importance score $=($ mean score + max score $) / 2$ where the mean score is a weighted mean of the four groups, and the maximum is the maximum of the four groups (Table 7).

Using this scheme in the example of Table 7, the estuary obtains an overall score of 82.5 rather than the 65 obtained with a simple weighted average. It is proposed that the score for each group carries an equal weighting. This means that the weight of an individual species is inversely related to the number of species in the same taxonomic group.

\section{Development of a common scoring base}

The calculation of these scores from existing data yields a variety of ranges of scores for each attribute. These scores need to be adjusted to a common scoring base before their incorporation into an overall index. A common method of dealing with this problem is to normalise the scores on a scale of 0 to 100 , where the maximum and minimum scores are converted to 100 and 0 , respectively, and intermediary scores are scaled accordingly. Applying this system resulted in strongly skewed distributions of scores, but with skewness differing from one attribute to the next. This means that a site scoring 50 for an attribute may rank very differently from a site scoring 50 for another attribute. Thus, in order to 'smooth' these distributions, we settled on a system of percentiles. For each index described above, the estuaries falling within each $10 \%$ percentile were given a score of 100, 90, 80, and so on (Table 8). Because of the skewness of scores, this means that there is often a considerable range of scores within a percentile category (especially in the case of estuary size).

\section{Construction of the estuary importance index}

Weights need to be assigned to each attribute in the construction of an overall index to reflect their relative impact on overall importance. These weights effectively stretch or shrink the scales of each attribute score. Weights were given to the attributes in a workshop setting. Specialists first ranked different estuaries which differed from each other only by attribute score, in order to bring to their attention the range of impact of a change in level of each different attribute. Following this, relative weights were agreed on for the different attributes, with and without considering functional importance as an attribute (Table 9).

The weightings originally devised were for use in the RDM process, but were adjusted for use with the preliminary data available for this analysis. Estuary size was given a relatively greater weighting to be used as a proxy for the lack of biological data and functional importance data for many estuaries, and for the lack of abundance or biomass data in most cases, even where species richness is known. Secondly, within the biodiversity importance index, the four biotic groups were not weighed equally, but invertebrates were down-weighted to $10 \%$, with the other groups each weighted as $30 \%$. The invertebrate data were very coarse, having a much smaller range of scores than would be the case with empirical data, and potentially overestimating the invertebrate score in many estuaries. In the analysis, where biodiversity data were missing for one or more taxa, the biodiversity importance score was taken as a mean of the existing scores, excluding missing scores. However, where size or habitat data were missing altogether, specialist opinion was used to assign a score. 


\begin{tabular}{|c|c|c|c|c|c|c|c|}
\hline \multicolumn{8}{|c|}{$\begin{array}{l}\text { TABLE } 8 \\
\begin{array}{c}\text { Adjusted importance scores from scores calculated for the different components of the estuary } \\
\text { importance index, giving type of data that each score is based on }\end{array}\end{array}$} \\
\hline \multirow[t]{2}{*}{$\begin{array}{l}\text { Adjusted } \\
\text { importance } \\
\text { score }\end{array}$} & Size & ZTR & $\begin{array}{l}\text { Habitat } \\
\text { rarity }\end{array}$ & $\begin{array}{l}\text { Plant } \\
\text { rarity } \\
\text { score }\end{array}$ & $\begin{array}{l}\text { Invertebrate } \\
\text { rarity } \\
\text { score }\end{array}$ & $\begin{array}{l}\text { Fish } \\
\text { rarity } \\
\text { score }\end{array}$ & $\begin{array}{l}\text { Bird } \\
\text { rarity } \\
\text { score }\end{array}$ \\
\hline & [Area (ha)] & - & [Area (ha)] & $\begin{array}{l}\text { [Presence- } \\
\text { absence] }\end{array}$ & $\begin{array}{c}\text { [Distributional } \\
\text { presence/absence] }\end{array}$ & [Abundance] & [Abundance] \\
\hline 10 & $0-1.5$ & 1 & $0.0-0.3$ & $0-0.5$ & $0-93$ & $0-2.5$ & $0-0.05$ \\
\hline 20 & $1.6-4$ & 3 & $0.31-0.9$ & $0.6-3.5$ & $93.1-95$ & $2.6-5.5$ & $0.06-0.25$ \\
\hline 30 & $4.1-8.5$ & 6 & $0.91-1.5$ & $3.6-7$ & $95.1-97.9$ & $5.6-9$ & $0.26-0.75$ \\
\hline 40 & $8.6-12.5$ & - & $1.51-2.5$ & $7.1-11$ & $98-100$ & $9.1-12.5$ & $0.76-1.50$ \\
\hline 50 & $12.6-17.5$ & 17 & $2.51-5.0$ & $11.1-17$ & $100.1-102 *$ & $12.6-17.5$ & $1.51-2.75$ \\
\hline 60 & $17.6-30$ & 20 & $5.1-10$ & $17.1-25$ & & $17.6-22.5$ & $2.76-5.00$ \\
\hline 70 & $30.1-50$ & 25 & $10.1-15$ & $25.1-35$ & $102.1-110$ & $22.6-37$ & $5.01-10$ \\
\hline 80 & $50.1-100$ & 33 & $15.1-25$ & $35.1-50$ & $110.1-120$ & $37.1-61.5$ & $10.1-20$ \\
\hline 90 & $100.1-200$ & 50 & $25.1-50$ & $50-100$ & $120.1-125$ & $61.6-90$ & $20.1-60$ \\
\hline 100 & $>200$ & 100 & $>50$ & $>100$ & $>125$ & $>90$ & $>60$ \\
\hline
\end{tabular}

\begin{tabular}{|l|c|c|}
\hline \multicolumn{3}{|c|}{ TABLE 9 } \\
$\begin{array}{c}\text { Construction of the estuary importance index, and the adjusted weighting system } \\
\text { used when Functional Importance was excluded from the analysis }\end{array}$ \\
\hline Criterion & Weights & $\begin{array}{c}\text { Weights } \\
\text { excluding last attribute }\end{array}$ \\
\hline Size & 15 & 40 \\
Zonal type rarity & 10 & 10 \\
Habitat diversity & 25 & 25 \\
Biodiversity importance & 25 & 25 \\
Functional importance & 25 & \\
ESTUARY IMPORTANCE SCORE = Weighted Mean & & \\
\hline
\end{tabular}

\section{Results: Conservation importance and estuaries requiring protected area status}

\section{Estuary ranking in terms of conservation importance}

The top 50 estuaries from the prioritisation exercise are shown in Table 10. The full results, with estuaries presented from west to east, are given in Appendix 1. Most of the estuaries near the top of the list are large systems, as to be expected. However, the ordering of the top few estuaries was carried out by biologists whose perception of estuarine importance is centred on biodiversity importance alone. These patterns are clearly influenced by zonal type rarity, which brings estuaries such as Knysna to a higher position than St. Lucia. Nevertheless, the top scores differ by small margins, and rankings within such close scores are somewhat arbitrary. Changing the weightings of the component criteria causes minor changes to these orderings, but no major changes.

It should be noted that among the top 50 estuaries, only eight are from the stretch of coastline from Tyolomnqa to the Mkomazi, which contains more than half (about 136) of the country's estuaries. This is probably largely due to the predominance of very small estuaries along this stretch, but may also have been to some extent an artefact of a relative lack of information on these estuaries, especially for birds. Many of these estuaries are in far better condition than the estuaries featured in Table 10.

Estuary rankings obtained in this study differ from the results of single-taxa analyses that have been carried out for plants, fish and birds (Table 11), due to combining all taxa as well as other attributes. The most important concern is that the top-ranking estuaries based on the different taxa are included in the top-ranking (i.e. scoring above 80) estuaries in the overall analysis (this study), with the exception of Nxaxo, Matigulu, Nhlabane and Durban Bay (Table 11).

There is, however, a notable difference between the results based on the fish importance rating and the estuaries classified as important for fish in this study: only 10 out of the top 25 estuaries are shared (Maree et al., 2000). Most of the parameters used in the FIR were intended as a proxy for fish abundance data, while actual abundance data were used in this study. The main difference between the two indices is that the FIR also reflects importance in terms of exploitable species. 


\begin{tabular}{|c|c|c|c|c|c|c|c|c|c|c|c|c|c|}
\hline \multirow[b]{2}{*}{ Rank } & \multicolumn{13}{|c|}{$\begin{array}{l}\text { TABLE } 10 \\
\text { The top } 50 \text { South African estuaries ranked in terms of conservation importance (IMP). } \\
\text { Conservation importance is calculated on the basis of weighted size (S), habitat }(\mathrm{H}) \text {, } \\
\text { zonal type rarity (Z) and biodiversity (B) importance scores }\end{array}$} \\
\hline & Estuary & s & $\mathbf{H}$ & Z & B & IMP & Rank & Estuary & $\mathbf{s}$ & $\mathbf{H}$ & $\mathbf{z}$ & B & IMP \\
\hline 1 & Knysna & 100 & 100 & 100 & 99.0 & 99.8 & 26 & Richard's Bay & 100 & 50 & 80 & 85.0 & 81.8 \\
\hline 2 & Berg & 100 & 100 & 90 & 94.0 & 97.5 & 27 & Kariega & 90 & 80 & 20 & 94.0 & 81.5 \\
\hline 3 & Olifants & 100 & 100 & 90 & 94.0 & 97.5 & 28 & Mbashe & 90 & 90 & 30 & 80.0 & 81.5 \\
\hline 4 & Kosi & 100 & 100 & 70 & 99.5 & 96.9 & 29 & Mtata & 90 & 90 & 30 & 79.0 & 81.3 \\
\hline 5 & St Lucia & 100 & 100 & 70 & 98.5 & 96.6 & 30 & Mkomazi & 100 & 60 & 30 & 90.0 & 80.5 \\
\hline 6 & Swartvlei & 100 & 100 & 70 & 97.0 & 96.3 & 31 & Kowie & 90 & 80 & 20 & 89.0 & 80.3 \\
\hline 7 & Orange & 100 & 100 & 90 & 88.0 & 96.0 & 32 & Goukou & 90 & 90 & 20 & 76.5 & 79.6 \\
\hline 8 & Bot/Kleinmond & 100 & 100 & 70 & 94.5 & 95.6 & 33 & Duiwenhoks & 90 & 90 & 20 & 75.0 & 79.3 \\
\hline 9 & Klein & 100 & 100 & 70 & 93.0 & 95.3 & 34 & Uilkraals & 90 & 90 & 10 & 77.5 & 78.9 \\
\hline 10 & Mhlathuze & 100 & 100 & 80 & 82.0 & 93.5 & 35 & Matigulu/Nyoni & 90 & 70 & 30 & 89.0 & 78.8 \\
\hline 11 & Swartkops & 100 & 100 & 20 & 100.0 & 92.0 & 36 & Mzimvubu & 90 & 90 & 30 & 67.0 & 78.3 \\
\hline 12 & Great Fish & 100 & 100 & 20 & 97.0 & 91.3 & 37 & Xora & 90 & 80 & 30 & 75.5 & 77.9 \\
\hline 13 & Mfolozi & 90 & 100 & 70 & 92.5 & 91.1 & 38 & Mgeni & 80 & 90 & 10 & 88.5 & 77.6 \\
\hline 14 & Gamtoos & 100 & 100 & 20 & 95.5 & 90.9 & 39 & Sundays & 90 & 70 & 20 & 87.5 & 77.4 \\
\hline 15 & Keiskamma & 100 & 100 & 20 & 93.5 & 90.4 & 40 & Nhlabane & 100 & 50 & 70 & 70.0 & 77.0 \\
\hline 16 & Keurbooms & 100 & 90 & 20 & 94.5 & 88.1 & 41 & Nxaxo/Ngqusi & 90 & 80 & 10 & 79.5 & 76.9 \\
\hline 17 & Kromme & 100 & 90 & 20 & 87.5 & 86.4 & 42 & Kabeljous & 90 & 80 & 10 & 75.0 & 75.8 \\
\hline 18 & Breë & 100 & 90 & 20 & 85.5 & 85.9 & 43 & Seekoei & 90 & 80 & 10 & 74.0 & 75.5 \\
\hline 19 & Mtati & 100 & 100 & 10 & 79.0 & 85.8 & 44 & Bushmans & 90 & 60 & 20 & 89.5 & 75.4 \\
\hline 20 & Mlalazi & 90 & 90 & 30 & 94.0 & 85.0 & 45 & Mtentu & 80 & 80 & 30 & 81.0 & 75.3 \\
\hline 21 & Mgwalana & 100 & 100 & 10 & 75.0 & 84.8 & 46 & Sand & 90 & 70 & 10 & 81.5 & 74.9 \\
\hline 22 & Mngazana & 90 & 100 & 30 & 82.0 & 84.5 & 47 & Mzamba & 80 & 80 & 30 & 79.5 & 74.9 \\
\hline 23 & Mpekweni & 90 & 100 & 10 & 86.5 & 83.6 & 48 & Bira & 90 & 70 & 10 & 81.0 & 74.8 \\
\hline 24 & Wilderness & 90 & 70 & 70 & 89.5 & 82.9 & 49 & Groot Brak & 90 & 80 & 10 & 70.5 & 74.6 \\
\hline 25 & Heuningnes & 90 & 90 & 20 & 87.5 & 82.4 & 50 & Gourits & 90 & 60 & 20 & 83.0 & 73.8 \\
\hline
\end{tabular}

TABLE 11

Comparison of results of importance status of estuaries with respect to overall importance (EIR), botanical importance (BIR), fish importance (FIR) and birds (based on subjective analysis of separate indices - Turpie 1995). Top ranking estuaries which are also within the top ten according to the EIR are shown in bold, and the EIR status ( $A=$ score of 80 or more, $B=60$ or more, etc.) is shown

\begin{tabular}{|l|l|l|c|l|l|l|c|}
\hline Rank & EIR & BIR & $\begin{array}{c}\text { EIR Status } \\
\text { (this study) }\end{array}$ & FIR & $\begin{array}{c}\text { EIR Status } \\
\text { (this study) }\end{array}$ & Birds CSI & $\begin{array}{c}\text { EIR Status } \\
\text { (this study) }\end{array}$ \\
\hline 1 & Knysna & St Lucia & A & St Lucia & A & St Lucia & A \\
2 & Berg & Mngazana & A & Kosi & A & Berg & A \\
3 & Olifants & Knysna & A & Richard's Bay & A & Richard's Bay & A \\
4 & Kosi & Swartkops & A & Mhlathuze & A & Langebaan & not incl. \\
5 & St Lucia & Berg & A & Mlalazi & A & Orange & A \\
6 & Swartvlei & Olifants & A & Matigulu/Nyoni & B & Olifants & A \\
7 & Orange & Mbashe & A & Durban Bay & C & Rietvlei & B \\
8 & Bot & Nxaxo & B & Knysna & A & Verlorenvlei & not incl. \\
9 & Klein & Keiskamma & A & Nhlabane & B & Wilderness & A \\
10 & Mhlatuze & Mlalazi & A & Mtakatye & not incl. & Bot & A \\
\hline
\end{tabular}


TABLE 12

Estuaries with protected area status, and the cumulative contribution they make to the representation of estuarine biodiversity. Estuaries marked with a \# are only partially protected.

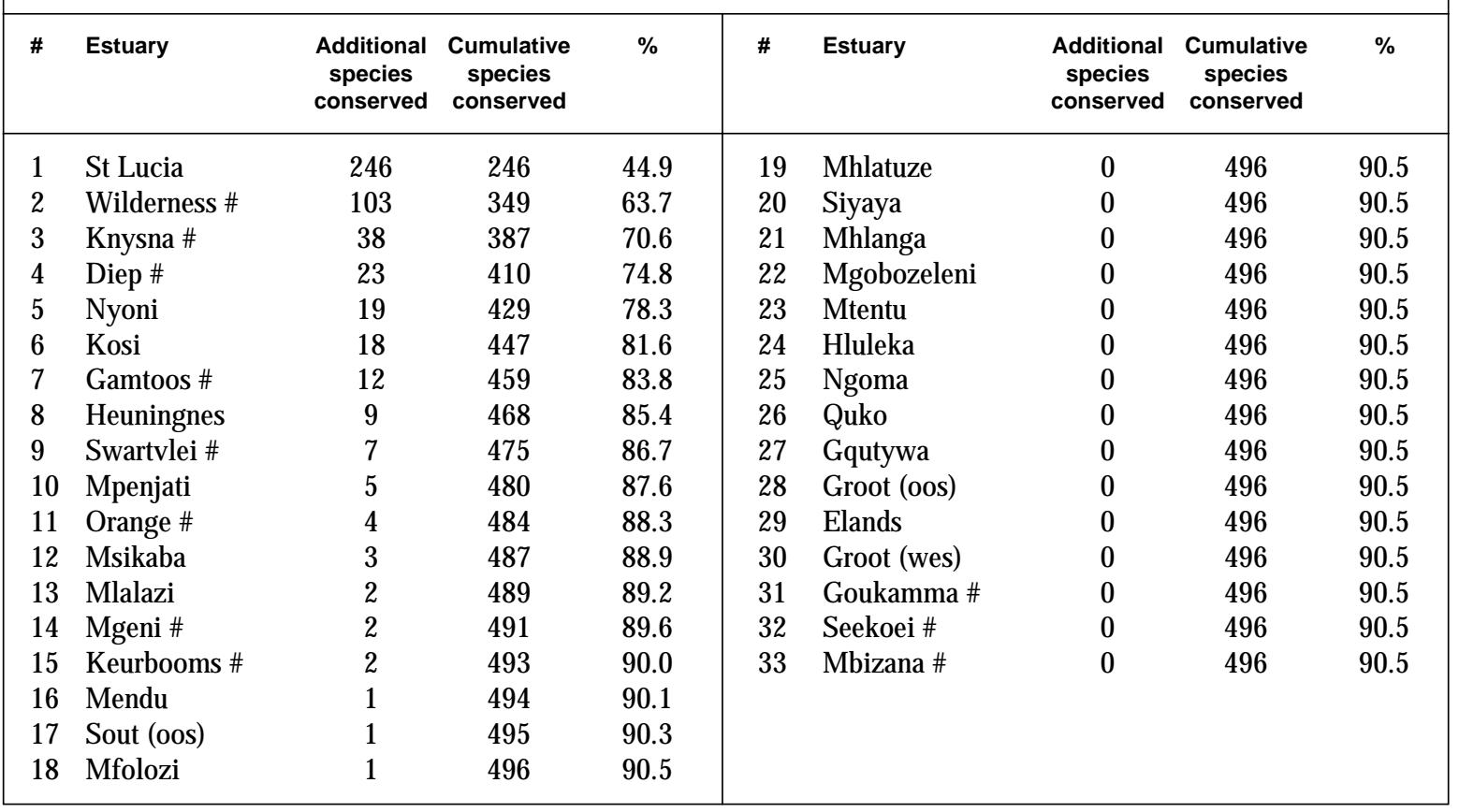

TABLE 13

Desired protected areas: Minimum set of estuaries required in a protected area network to represent $100 \%$ of species in the analysis, based on complementarity analysis. Estuaries, or portions thereof, which are already protected are marked with an asterisk.

\begin{tabular}{|c|c|c|c|c|c|c|c|c|c|}
\hline 1 & St Lucia* & 246 & 246 & 44.9 & 17 & Bot & 2 & 518 & 94.5 \\
\hline 2 & Berg & 95 & 341 & 62.2 & 18 & Bushmans & 1 & 519 & 94.7 \\
\hline 3 & Kosi* & 17 & 358 & 65.3 & 19 & Nhlabane & 1 & 520 & 94.9 \\
\hline 5 & Nyoni* & 16 & 448 & 81.8 & 21 & Mtamvuna & 3 & 525 & 95.8 \\
\hline 6 & Wildevoelvlei & 11 & 459 & 83.8 & 22 & Palmiet & 4 & 529 & 96.5 \\
\hline 7 & Wilderness* & 10 & 469 & 85.6 & 23 & Mvoti & 2 & 531 & 96.9 \\
\hline 8 & Manzimtoti & 4 & 473 & 86.3 & 24 & Great Kei & 2 & 533 & 97.3 \\
\hline 9 & Gouritz & 4 & 477 & 87.0 & 25 & Mgeni* & 2 & 535 & 97.6 \\
\hline 13 & Knysna* & 5 & 501 & 91.4 & 29 & Mlalazi* & 2 & 543 & 99.1 \\
\hline 14 & Keiskamma & 5 & 506 & 92.3 & 30 & Kromme & 2 & 545 & 99.5 \\
\hline 15 & Kariega & 6 & 512 & 93.4 & 31 & Goda & 2 & 547 & 99.8 \\
\hline 16 & Lovu & 4 & 516 & 94.2 & 32 & Mbashe & 1 & 548 & 100.0 \\
\hline
\end{tabular}




\begin{tabular}{|c|c|}
\hline \multicolumn{2}{|c|}{$\begin{array}{c}\text { TABLE } 14 \\
\text { Proposed rules for allocation of ERC, where EIS = estuary } \\
\text { importance score, PES = present ecological state, given as a } \\
\text { health class A to } \mathrm{F} \text {, and BAS = best attainable state }\end{array}$} \\
\hline $\begin{array}{l}\text { Current/future protection status } \\
\text { and biodiversity conservation importance }\end{array}$ & ERC \\
\hline $\begin{array}{l}\text { Protected area } \\
\text { Requiring Protected Area Status } \\
\text { EIS }=80-100 \text { (Highly important) } \\
\text { EIS }=60-80 \text { (Important) } \\
\text { EIS }=0-60 \text { (Of low to average importance) }\end{array}$ & $\begin{array}{l}\text { A or BAS } \\
\text { A or BAS } \\
\text { PES }+1, \min B, \text { or BAS } \\
\text { PES }+1, \text { min } C, \text { or BAS } \\
\text { PES, min D }\end{array}$ \\
\hline
\end{tabular}

\section{Existing estuarine protected areas (EPAs)}

A total of 33 estuaries in South Africa currently enjoy some degree of protected area status, although 11 of these are only partly protected (Whitfield ,1998; Table 12), and the status of some of these EPAs is effected primarily in protection afforded to surrounding areas and not to the estuary per se. The proclamation of protected areas in the past has, however, been on an ad hoc basis, rather than as part of a strategic national plan. Just over $90 \%$ of South Africa's estuarine species are represented (using rules of presence-absence described above) in these protected or semiprotected estuaries. In fact, this representation is achieved with just 18 of the estuaries.

\section{The 'ideal set' of EPAs}

Ideally, South Africa should have a reserve network of estuaries in which all estuarine species are represented and conserved. In this analysis, protected area priorities were determined with representativeness as the primary goal. The conservation of the top-scoring sites, as listed in Table 10, does not generally result in an efficient solution, as a number of species may only be present in lower-scoring sites. The top 10 and top 20 sites listed in Table 10 support only $84 \%$ and $89 \%$ of estuarine species, respectively. Although one can achieve representation of the majority of species by selecting the top sites in each biogeographical zone (Turpie, 1995), only the more sophisticated complementarity algorithms will select a perfectly efficient solution, in which all species are represented in the minimum set of sites (Turpie et al., 2000).

The results of a complementarity analysis showed that, without specifying any estuaries for inclusion at the outset, a set of 32 estuaries (11\% of South African estuaries) is required to represent $100 \%$ of estuarine species (Table 13). It should also be noted that only 12 estuaries are required to represent $90 \%$ of this diversity. Of the estuaries making up this set, 10 already enjoy protected area status.

If the complementarity analysis is run starting with the existing protected areas, then an additional 21 estuaries are required to represent all estuarine biodiversity. Although the total number of species are effectively represented in 39 of these, the total number of estuaries with protected area status would amount to 54 . In either case the total representation of estuarine species will require the proclamation of an additional 21 to 22 estuaries. Thus, the more pragmatic option is to strengthen the protected area status of the 10 protected areas included in the above list, and proclaim the 22 remaining estuaries in this list as estuarine protected areas. We classify the set of estuaries in Table 13 as "requiring protected area status".

\section{Discussion}

The results presented in this paper have been two years in the making, and, following several iterations and discussion sessions, are now widely accepted by the estuarine research community. We envisage these results as having two main applications: to aid in decision-making regarding the freshwater requirements of estuaries, and to aid in the development of a sound management strategy for the country's estuaries. We discuss each of these issues separately below.

\section{Application to the RDM process for determining freshwater requirements of estuaries}

The RDM process involves assigning a final management class (MC) to an estuary on the basis of its ecological reserve category (ERC) and other socio-economic criteria. The ERC is determined on the basis of the health and importance of an estuary. The MC is an expression of society's desired future state of health of the system, and determines the quantity and quality of water that needs to be allocated to the estuarine reserve, a higher reserve being associated with a healthier system. The MC may be higher or lower than the present state of health, depending on demands for allocating water to other uses, vs. demands for maintaining ecosystem goods and services (e.g. recreation, fisheries, etc.). The potential management class of an estuary ranges from A (near-pristine) to D (functional, but altered), whereas an estuary's present health may also be classed as $\mathrm{E}$ or $\mathrm{F}$ (totally degraded).

The ERC of an estuary will be allocated on the basis of its importance score, using the present ecological status (PES), or present health, as a starting point. We devised a system whereby the ERC can be determined on the basis of health and importance, so that a higher level of importance provides the motivation for improvement or maintenance of a higher level of health (Table 14). PES sets the minimum ERC. The degree to which ERC is higher than PES depends on level of importance, required level of protection, and the best attainable state (Table 14).

Note that estuaries classified as requiring protected area status are given special treatment in the setting of ERC (Table 14). We propose that it transcends this level of decision-making to have a strong influence in the final setting of the MC, even after taking socio-economic considerations into account. In other words, estuaries requiring protected area status should be guaranteed a relatively high estuarine water reserve in spite of other demands on this water supply. Whereas this may not lead to a welfaremaximising outcome from a local-level perspective, it is incumbent on the country to make provision for the conservation of biodiversity, 


\begin{tabular}{|c|c|c|c|c|c|c|}
\hline \multicolumn{7}{|c|}{$\begin{array}{c}\text { TABLE } 15 \\
\text { Intensity of management effort for different classes of estuary }\end{array}$} \\
\hline \multirow[t]{2}{*}{ Type of measure } & \multicolumn{6}{|c|}{ Type of estuary } \\
\hline & EPA & A & B & C & D & E \\
\hline No-go zones & $* * * *$ & $* * *$ & ** & ** & * & \\
\hline No-exploitation zones & $* * * *$ & $* * *$ & $* *$ & $* *$ & $*$ & \\
\hline Bag and size limits & $* * * *$ & $* * * *$ & $* * * *$ & $* * * *$ & $* * * *$ & $* * * *$ \\
\hline Effort control & $* * * *$ & $* * *$ & $* * *$ & $* * *$ & $* * *$ & $* * *$ \\
\hline Bordering no-development zones & $* * *$ & ** & $*$ & * & * & \\
\hline
\end{tabular}

as a signatory to the biodiversity convention. Moreover, there are other ways of ensuring water supply to affected parties (e.g. conservation measures to improve catchment run-off, economic incentive measures to reduce demands), or by ensuring that these communities benefit from having an estuarine protected area.

\section{Application to management}

Management of South African estuaries has been uncoordinated and irregular in the past. At present a hiatus in legal protection has effectively rendered estuaries 'free-for-all' areas, following a change-over from provincial legislation to the national level Marine Living Resources Act (Act 18 of 1998), which is still undergoing refinement. Nevertheless, with this recent transfer of estuary management responsibility to the Department of Environment Affairs and Tourism, an opportunity has arisen to start afresh, hopefully with a more strategic approach to this problem. Efforts have begun to develop a national plan and mechanisms for managing South Africa's estuaries and to provide guidelines and priorities for researchinitiatives (Boyd et al., 2000). However, it is fundamentally difficult to design a cross-cutting management strategy for estuaries, due to their variability in size, type, functioning and setting, with some estuaries in sparsely populated areas, others in popular holiday areas, and others playing an important role in subsistence economies. Nevertheless, the need has been identified to put a national estuarine protocol in place, which is non-negotiable and legislated, to compel local authorities to follow certain management procedures (Boyd et al., 2000). This study can contribute to the formulation of such a protocol, as follows.

Firstly, we propose a set of 32 estuaries that should be managed as EPAs if good representation of biodiversity is to be attained in protected areas. This is not to say that the biodiversity conservation is not required in the remaining estuaries (see below), but we strongly recommend that these selected estuaries, which represent only $11 \%$ of the country's estuaries, are afforded even higher levels of protection than other estuaries. These estuaries are highly representative of the national set, including all five types of estuaries and falling within all three biogeographical zones. Although they include a range of sizes, they do tend to be larger than average estuaries, as larger estuaries generally contain higher diversity and larger populations. However, it is their size that potentially presents the biggest political obstacle to their proclamation as protected areas. Large estuaries, such as the Swartkops Estuary, are often associated with intensive development and large catchments with important water supply potential. Thus it is important to consider what level of protection would be required for EPAs. Ideally, EPAs should be maintained as 'reference' systems maintained in a minimally-altered state. The purpose of
EPAs would be to secure stocks of the elements of biodiversity contained within them as well as provide the full economic benefits of ecosystem services provided by their functioning (e.g. nursery functions for maintaining coastal fisheries). Achieving such aims requires severe restrictions on consumptive and non-consumptive activities and on-site developments, as well as restricting catchment activities that affect water supply, siltation and pollution. For some of the estuaries listed in Table 12, this can potentially be achieved. For others, such as the Swartkops Estuary, it would be more difficult. Yet removing the Swartkops Estuary from the list would mean increasing the list by several estuaries, suggesting that it might be more pragmatic to attempt to improve conditions in the Swartkops.

Secondly, we propose that an estuary's importance status, irrespective of protected area status, has a bearing on its level and type of management. It is not only EPAs that require management attention. While the economic consequences of alternative management scenarios have not been explored for South African estuaries, it is almost certain that in many cases greater value will be obtained from estuaries maintained in a well-functioning state than in those degraded by activities associated with short-term gains, such as over-exploitation and excessive developments. Moreover, it does not take detailed economic studies to show that over-exploitation and degradation carry a cost to future generations as well as affecting present benefits obtained from recreational activities and even marine fisheries.

While all estuaries require management and planning measures to maintain their productivity and functioning, we concede that different estuaries need to be maintained to maximise different types of benefits, and may best be managed in a state somewhat altered from the pristine condition. Estuaries which are important for recreation require different management approaches from those important for subsistence fisheries. Indeed, it is often the use of a resource itself which has the greatest impact on its supply.

In proposing the strict protection of $11 \%$ of South Africa's estuaries, we do not suggest that the remaining estuaries be allowed to degrade through lack of management. The priority ranking provided in this study should be used to guide a national-level management strategy for estuaries. We suggest that estuaries are classified on the basis of their EIS scores, into five different categories, A to E, based on scores of 80 to 100,60 to 80 , etc., and that the intensity of conservation management is allotted accordingly (Table 15). Past management practices have concentrated on exploitation, mainly through size and bag limits and gear regulations, but these have become increasingly ineffective, due to a lack of enforcement and in some cases, turning of a blind eye to illegal methods of fishing or bait collection for political reasons. Zonation has seldom been implemented, but is a promising tool for curbing 
exploitation and human disturbance of estuaries, and is far easier to police. Clearly much work has to be done to find effective institutions and strategies for achieving wise use of South African estuaries. These processes cannot be implemented simultaneously for all estuaries, but should be implemented as a matter of priority in high ranking (Class A and B) estuaries.

\section{Acknowledgements}

This research was funded by the Department of Water and Environmental Affairs - Social and Ecological Services and the Water Research Commission. We are grateful to Barbara Weston, Heather MacKay and two anonymous referees for their inputs and comments on the manuscript.

\section{References}

AWAD AA, GRIFFITHS CL and TURPIE JK (2000) Distribution and Endemicity Patterns of Marine Benthic Invertebrates in South Africa Applied to the Selection of Priority Conservation Areas. M.Sc. thesis, University of Cape Town.

ADAMS JB, TALJAARD S, TURPIE JK and WHITFIELD AK (1999) Volume 5:Estuarine Ecosystems, Version 1.0. In: H Mackay and B Weston (eds.) Resource Directed Measures for Protection of Water Resources. Department of Water Affairs and Forestry, Pretoria.

BOYD AJ, BARWELL L and TALJAARD S (2000). Report on the National Estuaries Workshop, Port Elizabeth, May 2000. http:// www.environment.gov.za/mcm/econom/estintro.htm.

BRANCH GM, GRIFFITHS CL, BRANCH ML and BECKLEY L (1994) Two Oceans. A guide to the marine life of Southern Africa. David Philip, Cape Town.

CERM (1996). A Co-ordinated Research Programme on Decision Support for the Conservation and Management of Estuaries. Unpublished report to the Water Research Commission.

COETZEE JC, ADAMS JB and BATE GC (1997). A botanical importance rating of selected Cape estuaries. Water SA 2381 - 93.

COLLOTY BM (2000) Database of Estuarine Habitats on Compact Disc. University of Port Elizabeth.

COLLOTY BM, ADAMS JB and BATE GC (1998) The use of a botanical importance rating to assess changes in the flora of the Swartkops estuary over time. Water SA 26 171-180.

COLLOTY BM, ADAMS JB and BATE GC (2000) The Botanical Importance of the Estuaries in Former Ciskei/Transkei. WRC report 812/1/00. $150 \mathrm{pp}$.

COOPER JAG (1991). Sedimentary Models and Geomorphological Classification of River Mouths on a Subtropical, Wave-Dominated Coast, Natal, South Africa. Ph.D. thesis, University of Natal, Durban.

COWAN GI and VAN RIET W (1998) A Directory of South African Wwetlands. Department of Environmental Affairs and Tourism, Pretoria.

DAY JH (1967a) A Monograph of the Polychaeta of Southern Africa. 1. London: British Natural History Museum. 458 pp.
DAY JH (1967b) A Monograph of the Polychaeta of Southern Africa. 2. London: British Natural History Museum. 420pp.

DE VILLIERS C, HODGSON A and FORBES A (1999) Studies on estuarine macroinvertebrates. In: Allanson, BR \& Baird, D. (eds). Estuaries of South Africa. Cambridge University Press, pp 167-208.

EMANUEL BP, BUSTAMENTE RH, BRANCH GM, EEKHOUT S and ODENDAAL FJ. (1992) A zoogeographic and functional approach to the selection of marine reserves on the west coast of South Africa. S.A. J. Mar. Sci. 12 341-354.

HARRISON TD, COOPER JAG and RAMM AEL (2000) Geomorphology, ichthyofauna, water quality and aesthetics of South African estuaries. Unpublished CSIR report to the Department of Environmental Affairs \& Tourism ENV-DC-2000-001.

LOVE V (2000) Human Disturbance of Waterbirds in the Knysna Estuary, South Africa. M.Sc. thesis, University of Cape Town.

MAREE RC, WHITFIELD, AK and QUINN NW (2000). Prioritisation of South African Estuaries Based on their Potential Importance to Estuarine-Associated Fish Species. Unpublished report to Water Research Commission. 55pp.

PRESSEY RL, HUMPHRIES CJ, MARGULES CR, VANE-WRIGHT RI and WILLIAMS PH (1993) Beyond opportunism: key principles for systematic reserve selection. TREE 8 124-8.

RYAN PG and COOPER J (1985). Waders (Charadrii) and other coastal birds of the northwestern Cape Province, South Africa. Bontebok 4 18.

RYAN PG, COOPER J, HOCKEY PAR and BERRUTI A (1986) Waders (Charadrii) and other water birds on the coast and adjacent wetlands of Natal, 1980-1981. Lammergeyer 361 - 33.

RYAN PG, UNDERHILL LG, COOPER J and WALTNER M (1988) Waders (Charadrii) and other waterbirds on the coast, adjacent wetlands and off shore islands of the south-western Cape Province, South Africa. Bontebok 6 1-19.

TURPIE JK (1995) Prioritizing South African estuaries for conservation: a practical example using waterbirds. Biol. Conserv. 74 175-185.

TURPIE JK, BECKLEY LE and KATUA SM (2000) Biogeography and the selection of priority areas for conservation of South African coastal fishes. Biol. Conserv. 92 59-72.

UNDERHILL LG and COOPER J (1984) Counts of Waterbirds at Southern African Coastal Wetlands. Western Cape Wader Study Group and Percy FitzPatrick Institute of African Ornithology, Cape Town (Unpublished report).

WHITFIELD AK (1992) A characterisation of southern African estuarine systems. S. Afr. J. Aquat. Sci. 12 89-103.

WHITFIELD AK (1998) Biology and Ecology of Fishes in Southern African Estuaries. J.L.B. Smith Institute of Ichthyology, Grahamstown. WHITFIELD AK and MARAIS H (1999) The ichythofauna. In: Allanson BR and Baird D (eds.) Estuaries of South Africa. Cambridge University Press, pp 209-234.

WHITFIELD AK (2000) Available Scientific Information on Individual South African Estuarine Systems. Unpublished report, 139 pp.

WOOLDRIDGE TH (1999). Estuarine zooplankton community structure and dynamics. In: Allanson BR \& Baird D (eds.) Estuaries of South Africa. Cambridge University Press. 141-166. 


\section{APPENDIX 1}

Ranking of South African estuaries (ordered from west to east) in terms of conservation importance score (IMP), calculated on the basis of size (S), zonal type rarity $(\mathrm{Z})$, habitat importance $(\mathrm{H})$ and biodiversity importance $(\mathrm{B})$

\begin{tabular}{|c|c|c|c|c|c|c|c|c|c|c|c|c|c|}
\hline Rank & Estuary & $\mathbf{S}$ & $\mathbf{H}$ & $\mathbf{Z}$ & B & IMP & Rank & Estuary & S & $\mathbf{H}$ & $\mathbf{Z}$ & B & IMP \\
\hline 7 & Orange & 100 & 100 & 90 & 88.0 & 96.0 & 225 & Elands & 30 & 10 & 50 & 20.0 & 24.5 \\
\hline 3 & Olifants & 100 & 100 & 90 & 94.0 & 97.5 & 215 & Groot (Oos) & 30 & 10 & 50 & 33.0 & 27.8 \\
\hline 2 & Berg & 100 & 100 & 90 & 94.0 & 97.5 & 205 & Tsitsikamma & 30 & 20 & 10 & 49.0 & 30.3 \\
\hline 61 & Rietvlei/Diep & 100 & 10 & 60 & 85.5 & 69.9 & 216 & Klipdrif & 30 & 10 & 10 & 46.0 & 27.0 \\
\hline 177 & Houtbaai & 10 & 50 & 90 & 42.5 & 36.1 & 17 & Kromme & 100 & 90 & 20 & 87.5 & 86.4 \\
\hline 59 & Wildevoëlvlei & 60 & 90 & 60 & 72.0 & 70.5 & 43 & Seekoei & 90 & 80 & 10 & 74.0 & 75.5 \\
\hline 236 & Bokramspruit & 20 & 10 & 60 & 13.5 & 19.9 & 42 & Kabeljous & 90 & 80 & 10 & 75.0 & 75.8 \\
\hline 237 & Schuster & 20 & 10 & 60 & 13.5 & 19.9 & 14 & Gamtoos & 100 & 100 & 20 & 95.5 & 90.9 \\
\hline 190 & Krom & 20 & 10 & 60 & 72.0 & 34.5 & 125 & Van Stadens & 70 & 30 & 10 & 54.5 & 50.1 \\
\hline 191 & Silvermine & 10 & 50 & 10 & 65.0 & 33.8 & 182 & Maitland & 10 & 70 & 10 & 51.5 & 35.4 \\
\hline 46 & Sand & 90 & 70 & 10 & 81.5 & 74.9 & 11 & Swartkops & 100 & 100 & & 100.0 & 92.0 \\
\hline 153 & Eerste & 50 & 40 & 10 & 49.5 & 43.4 & 89 & Coega (Ngcura) & 70 & 40 & 10 & 80.0 & 59.0 \\
\hline 152 & Lourens & 40 & 30 & 10 & 75.5 & 43.4 & 39 & Sundays & 90 & 70 & 20 & 87.5 & 77.4 \\
\hline 187 & Sir Lowry's Pass & 30 & 20 & 10 & 66.5 & 34.6 & 99 & Boknes & 70 & 50 & 10 & 64.0 & 57.5 \\
\hline 238 & Steenbras & 20 & 10 & 20 & 27.5 & 19.4 & 44 & Bushmans & 90 & 60 & 20 & 89.5 & 75.4 \\
\hline 136 & Rooiels & 50 & 40 & 10 & 68.0 & 48.0 & 27 & Kariega & 90 & 80 & 20 & 94.0 & 81.5 \\
\hline 120 & Buffels (Oos) & 60 & 30 & 10 & 74.5 & 51.1 & 86 & Kasuka & 70 & 70 & 10 & 58.0 & 61.0 \\
\hline 73 & Palmiet & 70 & 60 & 20 & 76.5 & 64.1 & 31 & Kowie & 90 & 80 & 20 & 89.0 & 80.3 \\
\hline 8 & Bot/Kleinmond & 100 & 100 & 70 & 94.5 & 95.6 & 167 & Rufane & 50 & 10 & 10 & 63.0 & 39.3 \\
\hline 97 & Onrus & 70 & 60 & 10 & 55.5 & 57.9 & 91 & Riet & 50 & 80 & 10 & 71.0 & 58.8 \\
\hline 9 & Klein & 100 & 100 & 70 & 93.0 & 95.3 & 53 & Kleinemond Wes & 80 & 90 & 10 & 67.5 & 72.4 \\
\hline 34 & Uilskraals & 90 & 90 & 10 & 77.5 & 78.9 & 54 & Kleinemond Oos & 70 & 90 & 10 & 83.0 & 72.3 \\
\hline 203 & Ratel & 40 & 10 & 10 & 46.0 & 31.0 & 12 & Great Fish & 100 & 100 & 20 & 97.0 & 91.3 \\
\hline 25 & Heuningnes & 90 & 90 & 20 & 87.5 & 82.4 & 157 & Old woman's & 30 & 50 & 10 & 66.5 & 42.1 \\
\hline 235 & Klipdrifsfontein & 30 & 10 & 10 & 17.5 & 19.9 & 23 & Mpekweni & 90 & 100 & 10 & 86.5 & 83.6 \\
\hline 18 & Breë & 100 & 90 & 20 & 85.5 & 85.9 & 19 & Mtati & 100 & 100 & 10 & 79.0 & 85.8 \\
\hline 33 & Duiwenhoks & 90 & 90 & 20 & 75.0 & 79.3 & 21 & Mgwalana & 100 & 100 & 10 & 75.0 & 84.8 \\
\hline 32 & Goukou & 90 & 90 & 20 & 76.5 & 79.6 & 48 & Bira & 90 & 70 & 10 & 81.0 & 74.8 \\
\hline 50 & Gourits & 90 & 60 & 20 & 83.0 & 73.8 & 82 & Gqutywa & 80 & 70 & 10 & 44.5 & 61.6 \\
\hline 207 & Blinde & 20 & 10 & 10 & 74.5 & 30.1 & 239 & Blue Krans & 20 & 30 & 10 & 10.0 & 19.0 \\
\hline 74 & Hartenbos & 70 & 60 & 10 & 80.5 & 64.1 & 94 & Mtana & 60 & 70 & 10 & 62.5 & 58.1 \\
\hline 96 & Klein Brak & 80 & 10 & 10 & 89.5 & 57.9 & 15 & Keiskamma & 100 & 100 & 20 & 93.5 & 90.4 \\
\hline 49 & Groot Brak & 90 & 80 & 10 & 70.5 & 74.6 & 131 & Ngqinisa & 50 & 60 & 10 & 54.5 & 49.6 \\
\hline 201 & Maalgate & 50 & 10 & 10 & 32.5 & 31.6 & 113 & Kiwane & 60 & 70 & 10 & 49.5 & 54.9 \\
\hline 240 & Gwaing & 20 & 10 & 10 & 26.0 & 18.0 & 51 & Tyolomnqa & 90 & 60 & 10 & 86.0 & 73.5 \\
\hline 199 & Kaaimans & 40 & 10 & 20 & 45.0 & 31.8 & 241 & Lilyvale & 20 & 10 & 10 & 25.5 & 17.9 \\
\hline 24 & Wilderness & 90 & 70 & 70 & 89.5 & 82.9 & 109 & Ncera & 70 & 50 & 10 & 56.0 & 55.5 \\
\hline 6 & Swartvlei & 100 & 100 & 70 & 97.0 & 96.3 & 245 & Mlele & 10 & 10 & 10 & 32.0 & 15.5 \\
\hline 68 & Goukamma & 100 & 40 & 10 & 65.5 & 67.4 & 180 & Mcantsi & 50 & 20 & 10 & 38.5 & 35.6 \\
\hline 1 & Knysna & 100 & 100 & 100 & 99.0 & 99.8 & 93 & Gxulu & 80 & 50 & 10 & 51.0 & 58.3 \\
\hline 223 & Noetsie & 40 & 10 & 10 & 20.0 & 24.5 & 143 & Goda & 60 & 30 & 10 & 54.5 & 46.1 \\
\hline 57 & Piesang & 80 & 80 & 10 & 71.0 & 70.8 & 247 & Hlozi & 10 & 10 & 10 & 28.5 & 14.6 \\
\hline 16 & Keurbooms & 100 & 90 & 20 & 94.5 & 88.1 & 233 & Hickman's & 30 & 10 & 10 & 27.0 & 22.3 \\
\hline 212 & Matjies/Bitou & 20 & 10 & 10 & 65.5 & 27.9 & 90 & Buffalo & 80 & 40 & 20 & 59.5 & 58.9 \\
\hline 83 & Sout (Oos) & 80 & 50 & 20 & 60.0 & 61.5 & 218 & Blind & 10 & 10 & 10 & 74.0 & 26.0 \\
\hline 81 & Groot (Wes) & 70 & 50 & 10 & 82.5 & 62.1 & 244 & Hlaze & 20 & 10 & 10 & 19.0 & 16.3 \\
\hline 102 & Bloukrans & 80 & 10 & 50 & 68.5 & 56.6 & 60 & Nahoon & 80 & 60 & 20 & 84.0 & 70.0 \\
\hline 186 & Lottering & 60 & 10 & 50 & 13.5 & 34.9 & 70 & Qinira & 80 & 70 & 10 & 62.0 & 66.0 \\
\hline 210 & Elandsbos & 40 & 10 & 50 & 20.0 & 28.5 & 69 & Gqunube & 80 & 50 & 20 & 81.0 & 66.8 \\
\hline 144 & Storms & 80 & 10 & 50 & 26.5 & 46.1 & 78 & Kwelera & 80 & 60 & 20 & 58.0 & 63.5 \\
\hline
\end{tabular}




\begin{tabular}{|c|c|c|c|c|c|c|c|c|c|c|c|c|c|}
\hline Rank & Estuary & S & $\mathbf{H}$ & $\mathbf{Z}$ & B & IMP & Rank & Estuary & $\mathbf{S}$ & $\mathbf{H}$ & $\mathbf{Z}$ & B & IMP \\
\hline 112 & Bulura & 70 & 50 & 10 & 54.0 & 55.0 & 151 & Sinangwana & 50 & 30 & 10 & 61.5 & 43.9 \\
\hline 246 & Cunge & 10 & 10 & 10 & 30.5 & 15.1 & 22 & Mngazana & 90 & 100 & 30 & 82.0 & 84.5 \\
\hline 105 & Cintsa & 70 & 50 & 10 & 57.5 & 55.9 & 139 & Mngazi & 60 & 20 & 10 & 68.0 & 47.0 \\
\hline 76 & Cefane & 80 & 80 & 10 & 43.0 & 63.8 & 195 & Bululo & 20 & 30 & 10 & 66.5 & 33.1 \\
\hline 95 & Kwenxura & 70 & 50 & 10 & 65.5 & 57.9 & 165 & Mtambane & 60 & 20 & 10 & 37.5 & 39.4 \\
\hline 135 & Nyara & 60 & 40 & 10 & 52.5 & 48.1 & 36 & Mzimvubu & 90 & 90 & 30 & 67.0 & 78.3 \\
\hline 219 & Haga-haga & 30 & 20 & 10 & 30.5 & 25.6 & 221 & Ntlupeni & 30 & 10 & 10 & 38.0 & 25.0 \\
\hline 175 & Mtendwe & 50 & 40 & 10 & 24.0 & 37.0 & 142 & Nkodusweni & 70 & 40 & 10 & 30.0 & 46.5 \\
\hline 110 & Quko & 70 & 40 & 10 & 65.5 & 55.4 & 75 & Mntafufu & 60 & 70 & 30 & 78.0 & 64.0 \\
\hline 146 & Morgan & 60 & 30 & 10 & 49.5 & 44.9 & 101 & Mzintlava & 80 & 50 & 30 & 36.5 & 56.6 \\
\hline 232 & Cwili & 20 & 10 & 10 & 43.5 & 22.4 & 217 & Mzimpunzi & 40 & 20 & 10 & 17.0 & 26.3 \\
\hline 52 & Great Kei & 90 & 70 & 20 & 70.0 & 73.0 & 71 & Mbotyi & 80 & 70 & 10 & 60.5 & 65.6 \\
\hline 209 & Gxara & 10 & 40 & 10 & 54.5 & 28.6 & 178 & Mkozi & 30 & 30 & 10 & 62.5 & 36.1 \\
\hline 162 & Ngogwane & 50 & 30 & 10 & 46.5 & 40.1 & 242 & Myekane & 20 & 10 & 10 & 23.5 & 17.4 \\
\hline 79 & Qolora & 60 & 90 & 10 & 64.0 & 63.5 & 183 & Lupatana & 30 & 40 & 10 & 49.5 & 35.4 \\
\hline 197 & Ncizele & 40 & 10 & 10 & 54.5 & 33.1 & 173 & Mkweni & 40 & 60 & 10 & 23.5 & 37.9 \\
\hline 100 & Kobonqaba & 70 & 50 & 20 & 57.5 & 56.9 & 98 & Msikaba & 60 & 50 & 30 & 73.0 & 57.8 \\
\hline 41 & Nxaxo/Ngqusi & 90 & 80 & 10 & 79.5 & 76.9 & 118 & Mgwegwe & 40 & 80 & 10 & 63.5 & 52.9 \\
\hline 198 & Cebe & 20 & 40 & 10 & 55.5 & 32.9 & 200 & Mgwetyana & 30 & 10 & 10 & 65.0 & 31.8 \\
\hline 172 & Gqunqe & 40 & 40 & 10 & 43.5 & 37.9 & 45 & Mtentu & 80 & 80 & 30 & 81.0 & 75.3 \\
\hline 148 & Ngqwara & 50 & 40 & 10 & 54.0 & 44.5 & 166 & Sikombe & 50 & 50 & 10 & 23.5 & 39.4 \\
\hline 176 & Sihlontlweni/Gcini & 50 & 20 & 10 & 43.5 & 36.9 & 206 & Kwanyana & 40 & 10 & 10 & 43.0 & 30.3 \\
\hline 64 & Qora & 80 & 70 & 20 & 67.5 & 68.4 & 126 & Mnyameni & 70 & 40 & 30 & 36.5 & 50.1 \\
\hline 196 & Jujura & 40 & 10 & 10 & 54.5 & 33.1 & 214 & Mpahlanyana & 30 & 10 & 10 & 49.5 & 27.9 \\
\hline 160 & Ngadla & 50 & 30 & 10 & 48.0 & 40.5 & 213 & Mpahlane & 30 & 10 & 10 & 49.5 & 27.9 \\
\hline 127 & Shixini & 60 & 40 & 20 & 56.0 & 50.0 & 47 & Mzamba & 80 & 80 & 30 & 79.5 & 74.9 \\
\hline 72 & Nqabara & 90 & 70 & 20 & 37.0 & 64.8 & 193 & Mtentwana & 50 & 20 & 10 & 30.0 & 33.5 \\
\hline 184 & Ngoma/Kobule & 50 & 40 & 10 & 17.5 & 35.4 & 85 & Mtamvuna & 80 & 50 & 10 & 63.0 & 61.3 \\
\hline 149 & Mendu & 60 & 40 & 10 & 37.0 & 44.3 & 250 & Zolwane & 10 & 20 & 10 & 16.5 & 14.1 \\
\hline 28 & Mbashe & 90 & 90 & 30 & 80.0 & 81.5 & 168 & Sandlundlu & 30 & 40 & 10 & 64.5 & 39.1 \\
\hline 140 & Ku-Mpenzu & 50 & 60 & 10 & 43.5 & 46.9 & 234 & Ku-boboyi & 20 & 20 & 10 & 31.0 & 21.8 \\
\hline \multirow[t]{2}{*}{138} & Ku-Bhula/ & & & & & & & & & & & & \\
\hline & Mbhanyana & 40 & 70 & 10 & 51.5 & 47.4 & 169 & Tongazi & 10 & 70 & 10 & 64.5 & 38.6 \\
\hline 108 & Ntlonyane & 70 & 50 & 10 & 56.5 & 55.6 & 230 & Kandandhlovu & 20 & 20 & 10 & 35.5 & 22.9 \\
\hline 133 & Nkanya & 60 & 50 & 10 & 47.0 & 49.3 & 116 & Mpenjati & 50 & 50 & 10 & 79.0 & 53.3 \\
\hline 37 & Xora & 90 & 80 & 30 & 75.5 & 77.9 & 103 & Umhlangankulu & 50 & 80 & 10 & 61.5 & 56.4 \\
\hline 211 & Bulungula & 10 & 40 & 10 & 52.0 & 28.0 & 220 & Kaba & 20 & 40 & 10 & 24.5 & 25.1 \\
\hline 226 & Ku-amanzimuzama & 30 & 20 & 10 & 24.5 & 24.1 & 114 & Mbizana & 50 & 70 & 10 & 63.0 & 54.3 \\
\hline 155 & Mncwasa & 60 & 20 & 10 & 50.5 & 42.6 & 249 & Mvutshini & 10 & 20 & 10 & 16.5 & 14.1 \\
\hline 189 & Mpako & 50 & 30 & 10 & 24.5 & 34.6 & 137 & Bilanhlolo & 30 & 60 & 10 & 77.5 & 47.4 \\
\hline 150 & Nenga & 50 & 30 & 10 & 63.0 & 44.3 & 248 & Uvuzana & 10 & 20 & 10 & 18.0 & 14.5 \\
\hline 154 & Mapuzi & 60 & 30 & 10 & 42.0 & 43.0 & 204 & Kongweni & 20 & 40 & 10 & 47.0 & 30.8 \\
\hline 29 & Mtata & 90 & 90 & 30 & 79.0 & 81.3 & 222 & Vungu & 20 & 30 & 10 & 32.5 & 24.6 \\
\hline 67 & Mdumbi & 80 & 60 & 30 & 71.0 & 67.8 & 181 & Mhlangeni & 30 & 40 & 10 & 50.0 & 35.5 \\
\hline 192 & Lwandilana & 50 & 20 & 10 & 31.0 & 33.8 & 115 & Zotsha & 40 & 80 & 10 & 67.5 & 53.9 \\
\hline 145 & Lwandile & 60 & 40 & 10 & 44.0 & 46.0 & 208 & Boboyi & 20 & 40 & 10 & 42.5 & 29.6 \\
\hline 62 & Mtakatye & 90 & 70 & 30 & 50.5 & 69.1 & 224 & Mbango & 10 & 60 & 10 & 18.0 & 24.5 \\
\hline 188 & Hluleka/Majusini & 50 & 30 & 10 & 24.5 & 34.6 & 129 & Mzimkulu & 10 & 100 & 30 & 71.0 & 49.8 \\
\hline 107 & Mnenu & 80 & 60 & 10 & 31.0 & 55.8 & 122 & Mtentweni & 40 & 80 & 10 & 55.5 & 50.9 \\
\hline 119 & Mtonga & 70 & 50 & 10 & 44.0 & 52.5 & 229 & Mhlangamkulu & 30 & 10 & 10 & 29.5 & 22.9 \\
\hline 156 & Mpande & 50 & 30 & 10 & 56.5 & 42.6 & 171 & Damba & 20 & 90 & 10 & 26.0 & 38.0 \\
\hline
\end{tabular}




\begin{tabular}{|c|c|c|c|c|c|c|c|c|c|c|c|c|c|}
\hline Rank & Estuary & S & $\mathbf{H}$ & $\mathbf{Z}$ & B & IMP & Rank & Estuary & $\mathbf{S}$ & $\mathbf{H}$ & $\mathbf{Z}$ & B & IMP \\
\hline 185 & Koshwana & 20 & 80 & 10 & 24.5 & 35.1 & 106 & Manzimtoti & 40 & 70 & 10 & 85.5 & 55.9 \\
\hline 161 & Intshambili & 20 & 80 & 10 & 45.5 & 40.4 & 141 & Mbokodweni & 40 & 40 & 10 & 79.0 & 46.8 \\
\hline 123 & Mzumbe & 60 & 50 & 10 & 52.0 & 50.5 & 77 & Sipingo & 40 & 100 & 10 & 87.0 & 63.8 \\
\hline 147 & Mhlabatshane & 20 & 90 & 10 & 52.0 & 44.5 & 88 & Durban Bay & 10 & 100 & 80 & 91.5 & 59.9 \\
\hline 170 & Mhlungwa & 30 & 60 & 10 & 40.5 & 38.1 & 38 & Mgeni & 80 & 90 & 10 & 88.5 & 77.6 \\
\hline 163 & Mfazazana & 20 & 80 & 10 & 44.0 & 40.0 & 55 & Mhlanga & 90 & 70 & 10 & 69.5 & 71.9 \\
\hline 164 & Kwa-Makosi & 20 & 90 & 10 & 32.5 & 39.6 & 56 & Mdloti & 80 & 90 & 10 & 63.5 & 71.4 \\
\hline 202 & Mnamfu & 20 & 80 & 10 & 10.0 & 31.5 & 84 & Tongati & 70 & 80 & 10 & 49.5 & 61.4 \\
\hline 128 & Mtwalume & 60 & 50 & 10 & 49.0 & 49.8 & 65 & Mhlali & 60 & 90 & 10 & 82.5 & 68.1 \\
\hline 227 & Mvuzi & 10 & 50 & 10 & 23.0 & 23.3 & 174 & Seteni & 20 & 80 & 10 & 35.0 & 37.8 \\
\hline 87 & Fafa & 70 & 80 & 10 & 45.0 & 60.3 & 92 & Mvoti & 60 & 30 & 70 & 79.5 & 58.4 \\
\hline 243 & Mdesingane & 10 & 30 & 10 & 16.5 & 16.6 & 66 & Mdlotane & 70 & 90 & 10 & 65.5 & 67.9 \\
\hline 124 & Sezela & 50 & 50 & 10 & 67.5 & 50.4 & 121 & Nonoti & 60 & 60 & 10 & 44.5 & 51.1 \\
\hline 231 & Mkumbane & 10 & 40 & 10 & 29.5 & 22.4 & 63 & Zinkwasi & 60 & 90 & 10 & 84.5 & 68.6 \\
\hline 134 & Mzinto & 40 & 80 & 10 & 47.0 & 48.8 & 58 & Tugela/Thukela & 80 & 50 & 70 & 76.5 & 70.6 \\
\hline 228 & Mzimayi & 10 & 40 & 10 & 33.0 & 23.3 & 35 & Matigulu/Nyoni & 90 & 70 & 30 & 89.0 & 78.8 \\
\hline 179 & Mpambanyoni & 20 & 50 & 10 & 57.0 & 35.8 & 132 & Siyaya & 40 & 60 & 10 & 70.0 & 49.5 \\
\hline 158 & Mahlongwa & 40 & 40 & 10 & 58.5 & 41.6 & 20 & Mlalazi & 90 & 90 & 30 & 94.0 & 85.0 \\
\hline 130 & Mahlongwana & 40 & 80 & 10 & 50.5 & 49.6 & 10 & Mhlathuze & 100 & 100 & 80 & 82.0 & 93.5 \\
\hline 30 & Mkomazi & 100 & 60 & 30 & 90.0 & 80.5 & 26 & Richard's Bay & 100 & 50 & 80 & 85.0 & 81.8 \\
\hline 194 & Ngane & 20 & 40 & 10 & 57.0 & 33.3 & 40 & Nhlabane & 100 & 50 & 70 & 70.0 & 77.0 \\
\hline 104 & Umgababa & 60 & 60 & 10 & 63.5 & 55.9 & 13 & Mfolozi & 90 & 100 & 70 & 92.5 & 91.1 \\
\hline 111 & Msimbazi & 50 & 50 & 10 & 87.0 & 55.3 & 5 & St Lucia & 100 & 100 & 70 & 98.5 & 96.6 \\
\hline 80 & Lovu & 50 & 80 & 10 & 87.0 & 62.8 & 117 & Mgobezeleni & 20 & 80 & 70 & 72.0 & 53.0 \\
\hline 159 & Little Manzimtoti & 20 & 80 & 10 & 47.0 & 40.8 & 4 & Kosi & 100 & 100 & 70 & 99.5 & 96.9 \\
\hline
\end{tabular}

